\title{
Screening Potential Bioenergy Production of Tree Species in Degraded and Marginal Land in the Tropics
}

\author{
Nils Borchard ${ }^{1,2, *}$, Medha Bulusu ${ }^{1}$, Ann-Michelle Hartwig ${ }^{3}$, Matthias Ulrich ${ }^{4}$, Soo Min Lee ${ }^{5}$ \\ and Himlal Baral ${ }^{1}$ (B) \\ 1 Center for International Forestry Research, Jalan CIFOR, Situ Gede, Sindang Barang, Bogor 16115, Indonesia; \\ medha.bulusu@gmail.com (M.B.); H.Baral@cgiar.org (H.B.) \\ 2 Natural Resources Institute Finland (Luke), Plant Production, 00790 Helsinki, Finland \\ 3 Ruhr-University Bochum, Institute of Geography, Soil Science/Soil Ecology, Universitätsstrasse 150, \\ 44801 Bochum, Germany; ann-michelle.hartwig@rub.de \\ 4 Institute of Plant Production and Agroecology in the Tropics and Subtropics, University of Hohenheim, \\ 70593 Stuttgart, Germany; MatthiasUllrich@gmx.de \\ 5 National Institute of Forest Science, 57 Heogi-ro, Dongdaemu-gu, Seoul 02455, Korea; lesoomin@korea.kr \\ * Correspondence: nils.borchard@luke.fi; Tel.: +358-29-5322-201
}

Received: 2 August 2018; Accepted: 18 September 2018; Published: 23 September 2018

\begin{abstract}
Bioenergy can produce at least $25 \%$ of the global energy demand to combat climate change through reducing emissions in the energy sector. However, information on the bioenergy production potential of woody species and their suitability for silviculture on various soils in the humid tropics is limited. This review aims to identify tree species suitable for bioenergy production under these conditions. Data were compiled from 241 publications and nine freely available databases to assess environmental and silvicultural information on tropical tree species. Energy outputs were derived from the estimated productivity of the reviewed species and ranged from 0.2 to $24.0 \mathrm{Mg}$ biomass ha ${ }^{-1} \mathrm{yr}^{-1}, 0.1$ to $9.0 \mathrm{Mg}$ bio-oil ha ${ }^{-1} \mathrm{yr}^{-1}$, and 0.2 to $20.0 \mathrm{Mg}$ sugar ha $^{-1} \mathrm{yr}^{-1}$, equivalent to an energy yield between 2 and $444 \mathrm{GJ} \mathrm{ha}^{-1} \mathrm{yr}^{-1}$. As such, these bioenergy yields are within the range reported for the lignocellulosic biomass of energy crops cultivated in Europe, the USA, and Brazil. Our review identified some high-yielding species (e.g., Dyera polyphylla (Miq.) Steenis, Metroxylon sagu (Rottb.), Pongamia pinnata (L.)) and leguminous species that could be beneficial in mixed stands (e.g., Elaeis oleifera (Kunth) and Pongamia pinnata) or are suitable species to grow on wet or re-wetted peatland (Dyera polyphylla). However, there are limitations to cultivate woody bioenergy species on wet peatland. Sustainable methods for managing and harvesting forests, particularly on wet or re-wetted peatland, need to be developed.
\end{abstract}

Keywords: tropics; paludiculture; biomass; biofuel; biodiesel; bioethanol

\section{Introduction}

It is predicted that global energy demand will increase by $45 \%$ by 2040 compared to consumption in 2013, resulting in a total $\mathrm{CO}_{2}$ emission increase of $40 \%$ [1]. At the same time, achieving the $2{ }^{\circ} \mathrm{C}$ limit on global warming requires new policies to reduce the energy sector's $\mathrm{CO}_{2}$ emissions by replacing traditional and fossil fuels with renewable energies [1-3]. Bioenergy, energy produced from biological sources, is one such renewable energy [2,3]. Globally, bioenergy has the potential to produce $100-400$ exajoules (EJ) $\mathrm{yr}^{-1}$ [2,4], which is equivalent to $25 \%-100 \%$ of the total energy consumed in 2014 [5]. Despite such enormous potential, in 2014, only about $4 \%$ of the electricity and heat consumed were generated from biofuels, while traditional use of biomass (e.g., cooking) represented $9 \%$ of 
the energy consumed [5]. Traditional use of biomass, although common in developing countries, remains inefficient and hazardous to health; bioenergy could provide clean and affordable energy to meet increasing demands in these countries $[1,2,6]$. In the tropics, oil palm (Elaeis guineenis (Jacq.)) dominates biofuel production from tree species $[7,8]$. However, in comparison to forests, oil palm monoculture results in a loss of ecosystem functions [8]. This is less severe in mixed systems [9]; however, the advantages of mixed systems are countered by a reduction in palm oil yields due to the reduced number of stems per hectare. Diversifying or replacing palm oil plantations by including other oil crops (e.g., Pangamia pinnata) may offset oil yield loss. This has yet to be assessed.

The aim of this study was to identify tropical tree species that could produce biological resources for bioenergy production and are able to grow on various type of soils. The potential biofuel and energy yields were estimated by assessing yields based on silvicultural information (e.g., stem density) and productivity (e.g., biomass per ha and year), which were converted into energetic values (e.g., GJ ha ${ }^{-1} \mathrm{yr}^{-1}$ ). Due to the huge body of literature on species used and recommended for bioenergy production in the tropics, this study specifically focused on tree species for bioenergy production [10-13]. We therefore excluded bamboo and other non-woody species to avoid repetition of recent results produced by Abel et al. [11], Darabant et al. [14], Pfister [15], and Wi et al. [16].

\section{Materials and Methods}

The aim of this narrative review [17] was to identify tree species suitable for bioenergy systems in the tropics from literature [11-13,18-20] by combining their silvicultural information (Table 1) and potential energy yields per hectare per year (Table 2). A literature search using Google Scholar was conducted for silvicultural information using species names as keywords.

The search produced 241 documents and 9 freely available databases (Table S1). These were used to assess the following aspects of woody bioenergy crops: (i) botanical information (e.g., species and origin, synonyms, common name, typical use), (ii) ecological settings (e.g., temperature, mean annual precipitation, soil properties), and (iii) cropping and yields (e.g., stem density, biomass yield, bio-oil yield) (Table S2). Data extracted from original resources were taken directly from the publication; thus, our dataset represents original information without any conversion into a single system (e.g., FAO soil classification). Extracted soil $\mathrm{pH}$ values were mostly (i.e., 93\%, Table S2) published without further clarification on solutions used (e.g., $\mathrm{H}_{2} \mathrm{O}, \mathrm{KCl}, \mathrm{CaCl}_{2}$ ) or salt concentration, which affects the comparability of $\mathrm{pH}$ values [21,22]. Thus, due to the lower accuracy of $\mathrm{pH}$ values and ranges presented, this review can provide only approximate information on the soil $\mathrm{pH}$ values tolerated. Yield data in mass or volume per unit area were used as presented in surveys or calculations, based on single tree productivity (e.g., dry biomass, fruit yield, oil content) and stand density per unit area (Table S2). Conversion factors used to derive energy yields ( $\mathrm{JJ} \mathrm{ha}^{-1} \mathrm{yr}^{-1}$ ) were: (i) carbon density of 0.5 in dry mass of wood [23], (ii) energy of $37 \mathrm{MJ}$ stored per kg carbon or $19 \mathrm{MJ}$ per $\mathrm{kg}$ dry biomass [3], (iii) a bio-oil:biodiesel conversion rate of $90 \%$ (adapted from values published by Meher et al. [24], (iv) biodiesel density of $0.9 \mathrm{~g} \mathrm{~cm}^{-3}$ [24,25], (v) energy of $33 \mathrm{MJ}$ stored per liter of biodiesel [24,25], (vi) a sugar:bioethanol conversion rate of 51\% [26], (vii) bioethanol density of $0.8 \mathrm{~g} \mathrm{~cm}^{-3}$ [25], and (vii) energy of $21 \mathrm{MJ}$ per liter of bioethanol [25]. 
Table 1. Potential bioenergy species that tolerate unfavorable soil conditions. Soil conditions that are most relevant for species selection are presented. Potential ecological adaptations are also shown to inform about tolerances toward to for instance droughts and flooding. Primary data and their corresponding references are shown in Table S2.

\begin{tabular}{|c|c|c|c|c|c|}
\hline Species & Soil pH & Soil Texture & Soil Moisture & Soil Fertility & Additional Adaptations \\
\hline \multicolumn{6}{|c|}{ Species that tolerate poor soils, moist and dry environments } \\
\hline Agathis borneensis (Warb.) & $<7$ & $-/-$ & $-/-$ & $-/-$ & Deep, well-drained, acidic soil \\
\hline Aleurites moluccana (L.) & $5.0-8.0$ & $-/-$ & Moist to dry & Poor & Tolerates droughts \\
\hline Arenga pinnata (Wurmb.) & $-/-$ & Sand & Moist to dry & $-/-$ & Tolerates dry environments \\
\hline Azadirachta indica (A. Juss.) & $6.0-7.0$ & $-/-$ & $-/-$ & Poor & $-1-$ \\
\hline Borassus flabellifer (L.) & $5.0-6.0$ & $-/-$ & Moist to dry & $-/-$ & Tolerates droughts and short-term flooding \\
\hline Calliandra calothyrsus (Meisn.) & $5.0-6.5$ & $-/-$ & Moist to dry & Poor & Pioneer species, tolerates droughts \\
\hline Calophyllum inophyllum (L.) & $4.0-7.5$ & $-/-$ & Moist to dry & $-/-$ & Xerophytic species, tolerates droughts \\
\hline Ceiba pentandra $(\mathrm{L})$. & $-/-$ & Sandy & Moist & $-/-$ & Deep, well-drained, light soil, Andosol \\
\hline Croton megalocarpus (Hutch.) & $-/-$ & Sandy & Moist & $-/-$ & Pioneer species; deep, well-drained, light soil \\
\hline Croton tiglium (L.) & $4.5-7.5$ & $-/-$ & $-/-$ & $-/-$ & $-/-$ \\
\hline Gliricidia sepium (Jacq.) & $4.5-8.5$ & Various & Moist & $-/-$ & Pioneer species, deep, well-drained soil \\
\hline Neolamarckia cadamba (Roxb.) & $-/-$ & $-/-$ & Moist & $-/-$ & Deep, alluvial soils \\
\hline Pongamia pinnata (L.) & $-/-$ & Sandy & Moist to dry & $-/-$ & Deep soils, tolerates droughts and acidity \\
\hline Reutealis trisperma (Blanco) & $5.4-7.1$ & $-/-$ & $-/-$ & Poor & $-/-$ \\
\hline Vernicia fordii (Hemsl.) & $6.0-6.5$ & Sandy & Moist to dry & $-/-$ & Deep, well-drained, light soils \\
\hline Zapoteca tetragona (Willd.) & $-/-$ & $-/-$ & $-/-$ & $-/-$ & $-/-$ \\
\hline \multicolumn{6}{|c|}{ Species that tolerate permanently wet and waterlogged or temporarily flooded soils } \\
\hline Calamus caesius (Blume) & $-/-$ & Peat, clayish, silty & Moist to wet & $-1-$ & Margins of peat and swamp land, tolerates flooding \\
\hline Cerbera manghas (L.) & $-/-$ & $-/-$ & Moist to wet & $-/-$ & Riparian, swamp and mangrove environment \\
\hline Combretocarpus rotundatus (Miq.) & $3.0-4.5$ & Peat & Wet & $-/-$ & Peat-swamp forest (Shorea spp.), tolerates waterlogged soils \\
\hline Dyera polyphylla (Miq.) & $3.0-4.5$ & Peat & Wet & $-/-$ & Peat-swamp forest, wet soils, peat \\
\hline Erythrina excelsa (Baker) & $-/-$ & Various & Moist to wet & $-/-$ & Riparian and swamp land, high water table \\
\hline Euterpe oleracea (Mart.) & $-/-$ & Sandy & Moist & $-/-$ & Light soils, tolerates flooding \\
\hline Melaleuca cajuputi (Powell) & $-/-$ & Sandy & $-/-$ & Poor & Poor, well-drained soils, brackish and acidic sulfate soils \\
\hline Metroxylon sagu (Rottb.) & $>4.5$ & Various & Moist to wet & $-1-$ & Tolerates flooding \\
\hline Fleroya ledermannii (K.Krause) & $-/-$ & $-/-$ & $-/-$ & $-/-$ & Anemochory, tolerates flooding \\
\hline Nypa fruticans (Wurmb.) & 5.0 & Clayish & Moist to wet & $-/-$ & Mangrove species \\
\hline Palaquium ridleyi (King \& Gamble) & $3.0-4.5$ & Peat & Wet & $-/-$ & Peat-swamp forest \\
\hline Pentadesma butyracea (Sabine & $-/-$ & $-/-$ & $-/-$ & $-/-$ & Riparian forests, deep soils \\
\hline Phoenix reclinata (Jacq.) & $-/-$ & Various & $-/-$ & $-/-$ & Medium-to-fine textured soil, tolerates flooding \\
\hline Sandoricum koetjape (Burm.f.) & $\geq 7$ & Various & $-/-$ & Poor & Pioneer species, riparian areas \\
\hline Sesbania bispinosa (Jacq.) & $\overline{<10}$ & Various & Dry to wet & $-/-$ & Alkaline soils, riparian areas, tolerates droughts \\
\hline Spondias mombin (L.) & $4.3-8.0$ & Various & $-/-$ & $-/-$ & Various mineral soils, tolerates flooding \\
\hline Symphonia globulifera (L.f.) & $-/-$ & $-/-$ & Moist to wet & $-/-$ & Lowland rainforest to swamp forest \\
\hline
\end{tabular}


Table 2. Potential annual biomass, bio-oil, sugar ( $\mathrm{Su}$ ), and starch (St) productivity in $\mathrm{Mg} \mathrm{ha}^{-1} \mathrm{yr}^{-1}$ of species used/potentially suitable for forest-based bioenergy production in tropical regions. Biomass data were also converted into volumetric values ( $\left.\mathrm{mL} \mathrm{ha}^{-1} \mathrm{yr}^{-1}\right)$ and energy values $\left(\mathrm{GJ}\right.$ ha $\left.{ }^{-1} \mathrm{yr}^{-1}\right)$. A 'Yes' indicates a promising species, but due to a lack of information in the literature, yield could not be estimated. Primary data and their corresponding references are shown in Table S2.

\begin{tabular}{|c|c|c|c|c|c|c|c|c|}
\hline \multirow[t]{2}{*}{ Species } & \multicolumn{2}{|c|}{ Biomass } & \multicolumn{3}{|c|}{ Bio-Oil and Biodiesel } & \multicolumn{3}{|c|}{ Sugar or Starch and Bioethanol } \\
\hline & $\mathrm{Mg} \mathrm{ha}^{-1} \mathrm{yr}^{-1}$ & $\mathrm{GJ} \mathrm{ha}^{-1} \mathrm{yr}^{-1}$ & $\mathrm{Mg} \mathrm{ha}^{-1} \mathrm{yr}^{-1}$ & $\mathrm{~kL} \mathrm{ha}^{-1} \mathrm{yr}^{-1}$ & $\mathrm{GJ} \mathrm{ha}^{-1} \mathrm{yr}^{-1}$ & $\mathrm{Mg} \mathrm{ha}^{-1} \mathrm{yr}^{-1}$ & $\mathrm{~kL} \mathrm{ha}^{-1} \mathrm{yr}^{-1}$ & $\mathrm{GJ} \mathrm{ha}^{-1} \mathrm{yr}^{-1}$ \\
\hline \multicolumn{9}{|c|}{ Species that tolerate poor soils, moist and dry environments } \\
\hline Agathis borneensis (Warb.) & $1.0-1.7$ & 19-31 & $-/-$ & $-/-$ & $-/-$ & $-/-$ & $-/-$ & $-/-$ \\
\hline Aleurites moluccana (L.) & $3.6-5.7$ & $67-105$ & $0.5-6.0$ & $0.5-6.0$ & 16-194 & $-/-$ & $-/-$ & $-/-$ \\
\hline Arenga pinnata (Wurmb) & $-/-$ & $-/-$ & $-/-$ & $-/-$ & $-/-$ & $20(\mathrm{Su})$ & $2.0-12.8$ & $43-268$ \\
\hline Azadirachta indica (A.Juss.) & $-/-$ & $-/-$ & $0.1-2.7$ & $0.1-2.7$ & $4-87$ & $-/-$ & $-/-$ & $-/-$ \\
\hline Borassus flabellifer (L.) & $-/-$ & $-/-$ & $-/-$ & $-/-$ & $-/-$ & $20(\mathrm{Su})$ & $1.2-12.8$ & $25-268$ \\
\hline Calliandra calothyrsus (Meisn.) & $6.0-24.0$ & $111-444$ & $-/-$ & $-/-$ & $-/-$ & $-/-$ & $-/-$ & $-/-$ \\
\hline Calophyllum inophyllum (L.) & $-/-$ & $-/-$ & $2.0-6.0$ & $2.0-5.9$ & 65-194 & $-/-$ & $-/-$ & $-/-$ \\
\hline Ceiba pentandra (L.) & $-/-$ & $-/-$ & $1.3-4.8$ & $1.3-4.8$ & $42-155$ & $-/-$ & $-/-$ & $-/-$ \\
\hline Croton megalocarpus (Hutch) & $-/-$ & $-/-$ & $1.6-4.5$ & $1.6-4.5$ & $52-145$ & $-/-$ & $-/-$ & $-/-$ \\
\hline Croton tiglium (L.) & $-/-$ & $-/-$ & $0.2-0.9$ & $0.2-0.9$ & 6-29 & $-/-$ & $-/-$ & $-/-$ \\
\hline Gliricidia sepium (Jacq.) & $2.0-12.0$ & $37-222$ & $-/-$ & $-/-$ & $-/-$ & $-/-$ & $-/-$ & $-/-$ \\
\hline Neolamarckia cadamba (Roxb.) & $1.8-12.9$ & $33-239$ & $-/-$ & $-/-$ & $-/-$ & $-/-$ & $-/-$ & $-/-$ \\
\hline Pongamia pinnata (L.) & $-/-$ & $-/-$ & $0.9-9.0$ & $0.9-8.9$ & $29-290$ & $-/-$ & $-/-$ & $-/-$ \\
\hline Reutealis trisperma (Blanco) & $-/-$ & $-/-$ & Yes & $-/-$ & $-/-$ & $-/-$ & $-/-$ & $-/-$ \\
\hline Vernicia fordii (Hemsl.) & $-/-$ & $-/-$ & $0.3-1.0$ & $0.2-1.0$ & $8-32$ & $-/-$ & $-/-$ & $-/-$ \\
\hline Zapoteca tetragona (Willd.) & Yes & $-/-$ & $-/-$ & $-/-$ & $-/-$ & $-/-$ & $-/-$ & $-/-$ \\
\hline \multicolumn{9}{|c|}{ Species that tolerate continuously wet and waterlogged or temporarily flooded soils } \\
\hline Calamus caesius (Blume) & $1.5-3.0$ & $28-56$ & $-/-$ & $-/-$ & $-1-$ & $-/-$ & $-/-$ & $-/-$ \\
\hline Cerbera manghas (L.) & $-/-$ & $-/-$ & 2.2 & 2.2 & 71 & $-/-$ & $-/-$ & $-/-$ \\
\hline Combretocarpus rotundatus (Miq.) & $-/-$ & $-/-$ & $-/-$ & $-/-$ & $-/-$ & $-/-$ & $-/-$ & $-/-$ \\
\hline Dyera polyphylla (Miq.) & $5.4-14.0$ & $100-259$ & $-/-$ & $-/-$ & $-/-$ & $-/-$ & $-/-$ & $-/-$ \\
\hline Erythrina excelsa (Baker) & Yes & $-/-$ & $-/-$ & $-/-$ & $-/-$ & $-/-$ & $-/-$ & $-/-$ \\
\hline Euterpe oleracea (Mart.) & $-/-$ & $-/-$ & $-/-$ & $-/-$ & $-/-$ & $0.2-3.8(\mathrm{Su})$ & $0.1-2.4$ & $2-50$ \\
\hline Melaleuca cajuputi (Powell) & Yes & $-/-$ & $-/-$ & $-/-$ & $-/-$ & $-/-$ & $-/-$ & $-/-$ \\
\hline Metroxylon sagu (Rottb.) & $-/-$ & $-/-$ & $-/-$ & $-/-$ & $-/-$ & $15-24(\mathrm{St})$ & $9.6-15.3$ & $201-321$ \\
\hline Fleroya ledermannii (K.Krause) & $2.7-3.2$ & $49-59$ & $-/-$ & $-/-$ & $-/-$ & $-/-$ & $-/-$ & $-/-$ \\
\hline Nypa fruticans (Wurmb.) & $-/-$ & $-/-$ & $-/-$ & $-/-$ & $-/-$ & $3-22(\mathrm{Su})$ & $1.9-14.0$ & $40-295$ \\
\hline Palaquium ridleyi (King \& Gamble) & $-/-$ & $-/-$ & $-/-$ & $-/-$ & $-/-$ & $-/-$ & $-/-$ & $-/-$ \\
\hline Pentadesma butyracea (Sabine) & $-/-$ & $-/-$ & $0.6-8.0$ & $0.6-7.9$ & $20-258$ & $-/-$ & $-/-$ & $-/-$ \\
\hline Phoenix reclinata (Jacq.) & Yes & $-/-$ & $-/-$ & $-/-$ & $-/-$ & $-/-$ & $-/-$ & $-/-$ \\
\hline Sandoricum koetjape (Burm.f.) & $-/-$ & $-/-$ & $-/-$ & $-/-$ & $-/-$ & Yes & $-/-$ & $-/-$ \\
\hline Sesbania bispinosa (Jacq.) & $8.0-17.0$ & $148-315$ & $-/-$ & $-/-$ & $-/-$ & $-/-$ & $-/-$ & $-/-$ \\
\hline Spondias mombin (L.) & $0.2-0.6$ & $4-10$ & $-/-$ & $-/-$ & $-/-$ & $-/-$ & $-/-$ & $-/-$ \\
\hline Symphonia globulifera (L.f.) & Yes & $-/-$ & $-/-$ & $-/-$ & $-/-$ & $-/-$ & $-/-$ & $-/-$ \\
\hline
\end{tabular}

-/- no data available. 


\section{Results}

Although numerous woody species are suitable for forest-based bioenergy systems in humid tropical regions, the estimation of potential bioenergy yields per unit of area (i.e., GJ ha ${ }^{-1} \mathrm{yr}^{-1}$ ) was limited to 33 species due to the scarcity of silvicultural and biorefinery data (Tables 1 and 2). This study provides species-specific information on environments preferred by each species, silvicultural information (e.g., stem density per hectare), and yield data (Mg dry biomass ha ${ }^{-1} \mathrm{yr}^{-1}$ ). About 50\% of the species $(n=16)$ are adapted to mineral soils and able to tolerate acidic and nutrient-poor soils (e.g., eroded Acrisols) and droughts (Table 1). Trees that can tolerate drought include Aleuritis moluccana (L.), Calophyllum inophyllum (L.), and Pongamia pinnata. Although their cropping on terrestrial soils potentially produces high yields, such yields will be reduced by flooding and wet soil conditions. In addition, soil wetness, soil acidity, and low nutrient status may also limit plant productivity [27]. In particular, biological nitrogen fixation by leguminous species that have been widely used to rehabilitate degraded land (e.g., Calophyllum inophyllum, Gliricidia sepium (Jacq.)) is drastically reduced in acidic soils. Based on tree productivity data, and information on their silvicultural recommendations, species suitable for growth on mineral soils and (re)-wetted peatland (Tables 1 and 2) can potentially produce between 0.2 and $24.0 \mathrm{Mg}$ biomass ha $^{-1} \mathrm{yr}^{-1}, 0.1$ and $9.0 \mathrm{Mg}$ bio-oil ha ${ }^{-1} \mathrm{yr}^{-1}$, and between 0.2 and approximately $20.0 \mathrm{Mg}$ sugar ha $^{-1} \mathrm{yr}^{-1}$, which is equal to an energy yield between 2 and $444 \mathrm{GJ} \mathrm{ha}^{-1} \mathrm{yr}^{-1}$ (Tables 2 and S2).

Seventeen species are potentially suitable for bioenergy activities on wet land and land which is regularly flooded (Table 1). Three tree species tolerate brackish environments, namely Cerbera manghas (L.), Nypa fructicans (Wurmb.), and Melaleuca cajuputi (Powell). The energy yield potential of these species ranges between 71 and $295 \mathrm{GJ} \mathrm{ha}^{-1} \mathrm{yr}^{-1}$ (no data for Melaleuca cajuputi, Table 2). Calamus caesius (Blume) and Symphonia globulifera (L.f.) are adapted to wet soils rich in organic matter, while Combretocarpus rotundatus (Miq.) Danser, Dyera polyphylla, and Palaquium ridleyi (King \& Gamble) can grow on permanently wet organic soils (i.e., peatland). Although peatland species produce raw material for bioenergy activities, data on productivity and energy yields are rarely reported, with productivity data found only for Dyera polyphylla (Table 2). The remaining nine tree species presented in Table 2 tolerate flooding and produce biomass, bio-oil, and sugar. Again, although information found on yields and productivity are minimal, the estimated energy output of some species may be too low for bioenergy activities (e.g., Euterpe oleracea (Mart.), Fleroya ledermannii (K.Krause), Spondias mombin (L.)), while the estimated productivity of Pentadesma butyracea Sabine and Sesbania bispinosa (Jacq.) seems to be promising for bioenergy activities (Table 2). Other species in this group are promising bioenergy crop candidates, but information on their productivity is not readily available (Tables 2 and S2).

\section{Discussion}

The species presented that tolerate acidic soils and droughts are known and often used to produce raw material for bioenergy in tropical countries [12,13,28]. However, initiatives that aim to produce bioenergy require silvicultural information and yield data. The information presented here can be used to assess the economic feasibility of bioenergy projects and cropping system types [29-31]. Silvicultural and yield data are scarce for tropical tree species adapted to permanently wet and regularly flooded environments, but such data are required to develop feasible bioenergy strategies for wetlands (e.g., peatland). Two reasons could explain this knowledge gap: (i) limited interest in most of these tree species, except for sugar- and starch-producing palm trees (Metroxylon sagu, Nypa fructicans) and (ii) a lack of machinery for harvesting [32]. To avoid competition between food production and the production of raw materials for bioenergy, non-food crops should be cultivated on less productive land (e.g., eroded soil) $[3,6,28]$. The simplest approach to rehabilitating eroded land is the establishment of plantations [33]. Optimizing initial plant growth on eroded land for biomass production may require the application of fertilizer, which can cause the emission of $\mathrm{N}_{2} \mathrm{O}[3,34]$. A less-assessed, but promising, way to reduce the amount of $\mathrm{N}$-fertilizer is to mix non-leguminous 
and leguminous crops (e.g., Elaeis oleifera (Kunth) Cortés and Pongamia pinnata). Rehabilitation may require initial site preparation by planting species that can shade out weeds, fix nitrogen, and improve soil organic matter [33]. Trees suitable for site preparation are fast-growing, nitrogen-fixing species, e.g., Calliandra calothyrsus (Meisn.), Gliricidia sepium, and Zapoteca tetragona (Willd.). The cultivation of non-native tree species risks invasive competition [35-37]. Thus, introducing for example species native to Africa (i.e., Croton megalocarpus (Hutch)) and America (i.e., Spondias mombin) to Southeast Asia and could have negative impacts on biodiversity and environmental services.

The rehabilitation of wet land requires selection of species that can tolerate wet soils and are adapted to natural conditions of peat swamp forests (e.g., Dyera polyphylla) [32], yet there is limited information available on suitable trees for peat-swamp rehabilitation activities. In this study, bioenergy yields are compared to those of palm oil trees (Elaeis guineenis), which produce 3-6 Mg bio-oil $\mathrm{ha}^{-1} \mathrm{yr}^{-1}$ [38-40], equivalent to an energy output of 90-194 GJ ha ${ }^{-1}$. Most of the assessed species have the potential to produce raw material (Palaquium ridleyi, Sandoricum koetjape (Burm.f.)) generating the same level of energy. For some species, very high yields have been reported (e.g., Dyera polyphylla, Metroxylon sagu, Pongamia pinnata) $[19,41,42]$, potentially far above yields that are possible on degraded land. Other species with an estimated energy output of $<90 \mathrm{GJ} \mathrm{ha}^{-1} \mathrm{yr}^{-1}$ (i.e., the lowest energy output estimated for Elaeis oleifera) might not be feasible for bioenergy activities in tropical countries.

\section{Conclusions}

Tree species adapted to tropical wetlands and peatlands are potentially useful for bioenergy production, but published data are available only for a small number species. The estimated bioenergy yields of the reviewed woody species are in the range reported for lignocellulosic biomass of energy crops cultivated in Europe, the USA, and Brazil (110-370 GJ ha ${ }^{-1} \mathrm{yr}^{-1}$ ) [2,3]. However, the values and coefficients used to estimate energy yields per unit area may fail to reflect the real variability of caloric values of biomass from various species $[43,44]$. Thus, this study provides initial estimations, which should be verified by experiments to test the impact of silviculture and biorefinery methods on energy yields.

Supplementary Materials: The following are available online at http:/ /www.mdpi.com/1999-4907/9/10/594/s1, Table S1: References, Table S2: Data survey.

Author Contributions: Study concept and design: N.B. and H.B. Data collection: M.B., A.M.H., M.U., and N.B. Analysis and interpretation of data: N.B. and M.B. Drafting of the manuscript: N.B., M.B., A.M.H., and H.B. Critical revision of the manuscript: N.B., M.B., A.M.H., M.U., S.M.L., and H.B. Administrative, technical, and material support: H.B. and S.M.L. All the authors contributed to the discussion of the results and the final edition of the manuscript.

Acknowledgments: This research was carried out by the Center for International Forestry Research (CIFOR) as part of the CGIAR Research Program on Forests, Trees and Agroforestry (CRP-FTA), and funded by the National Institute of Forest Sciences, Korea. Nils Borchard was placed as an integrated expert at CIFOR by the Centre for International Migration and Development (CIM). CIM is a joint operation of the Deutsche Gesellschaft für Internationale Zusammenarbeit (GIZ) GmbH and the International Placement Services of the German Federal Employment Agency. Many thanks go to GIZ's Advisory Service on Agricultural Research for Development (BEAF) for supporting co-author Ms. Medha Bulusu during her thesis research at CIFOR. We also thank Jutta Zeitz for valuable comments and suggestions and Achmat Solichin for assisting during the literature survey. We thank three anonymous reviewers for their highly constructive comments.

Conflicts of Interest: The authors declare no conflict of interest.

\section{References}

1. IEA World Energy Outlook 2015. Available online: http:/ /www.iea.org/newsroom/news/2015/november/ world-energy-outlook-2015.html (accessed on 30 September 2016).

2. Faaij, A.P.C. Bio-energy in Europe: Changing technology choices. Energy Policy 2006, 34, 322-342. [CrossRef] 
3. Bioenergy-Chances and Limits; Anton, C.; Steinicke, H., Eds.; German National Academy of Sciences Leopoldina: Halle, Germany, 2012. Available online: http://www.leopoldina.org/en/publications / detailview / ?publication\%5Bpublication \%5D=434\&cHash=9daf8d722e71e30bf2901cf01ee800d1 (accessed on 30 September 2016).

4. Nijsen, M.; Smeets, E.; Stehfest, E.; van Vuuren, D.P. An evaluation of the global potential of bioenergy production on degraded lands. GCB Bioenergy 2012, 4, 130-147. [CrossRef]

5. REPORT-REthinking Energy 2017: Accelerating the Global Energy Transformation. 2017. Available online: http:/ / www.irena.org/documentdownloads/publications/irena_rethinking_energy_2017.pdf (accessed on 30 September 2016).

6. Balat, M.; Balat, H. Recent trends in global production and utilization of bio-ethanol fuel. Appl. Energy 2009, 86, 2273-2282. [CrossRef]

7. Proskurina, S.; Junginger, M.; Heinimö, J.; Tekinel, B.; Vakkilainen, E. Global biomass trade for energy-Part 2: Production and trade streams of wood pellets, liquid biofuels, charcoal, industrial roundwood and emerging energy biomass: Biomass trade for energy. Biofuel Bioprod. Biorefining 2018. [CrossRef]

8. Dislich, C.; Keyel, A.C.; Salecker, J.; Kisel, Y.; Meyer, K.M.; Auliya, M.; Barnes, A.D.; Corre, M.D.; Darras, K.; Faust, H.; et al. A review of the ecosystem functions in oil palm plantations, using forests as a reference system. Biol. Rev. 2017, 92, 1539-1569. [CrossRef] [PubMed]

9. Ashraf, M.; Zulkifli, R.; Sanusi, R.; Tohiran, K.A.; Terhem, R.; Moslim, R.; Norhisham, A.R.; Ashton-Butt, A.; Azhar, B. Alley-cropping system can boost arthropod biodiversity and ecosystem functions in oil palm plantations. Agric. Ecosyst. Environ. 2018, 260, 19-26. [CrossRef]

10. Duke, J.A. Handbook of Energy Crops. 1983. Available online: http://www.hort.purdue.edu/newcrop/ duke_energy/refa-f.html (accessed on 30 September 2016).

11. Abel, S.; Couwenberg, J.; Dahms, T.; Joosten, H. The Database of Potential Paludiculture Plants (DPPP) and results for Western Pomerania. Plant Divers. Evol. Vol. 2013, 130, 219-228. [CrossRef]

12. Biswas, B.; Scott, P.T.; Gresshoff, P.M. Tree legumes as feedstock for sustainable biofuel production: Opportunities and challenges. J. Plant Physiol. 2011, 168, 1877-1884. [CrossRef] [PubMed]

13. Atabani, A.E.; Silitonga, A.S.; Ong, H.C.; Mahlia, T.M.I.; Masjuki, H.H.; Badruddin, I.A.; Fayaz, H. Non-edible vegetable oils: A critical evaluation of oil extraction, fatty acid compositions, biodiesel production, characteristics, engine performance and emissions production. Renew. Sustain. Energy Rev. 2013, 18, 211-245. [CrossRef]

14. Darabant, A.; Haruthaithanasan, M.; Atkla, W.; Phudphong, T.; Thanavat, E.; Haruthaithanasan, K. Bamboo biomass yield and feedstock characteristics of energy plantations in Thailand. Energy Procedia 2014, 59, 134-141. [CrossRef]

15. Pfister, J. Sustainable Use of Wetlands in Northern Kwa-Zulu Natal-Linking Soil Properties, Crops Physiology and Land Use; Humboldt Universität zu Berlin: Berlin, Germany, 2016.

16. Wi, S.G.; Lee, D.-S.; Nguyen, Q.A.; Bae, H.-J. Evaluation of biomass quality in short-rotation bamboo (Phyllostachys pubescens) for bioenergy products. Biotechnol. Biofuels 2017, 10, 127. [CrossRef] [PubMed]

17. Uman, L.S. Systematic reviews and meta-analyses. J. Can. Acad. Child Adolesc. Psychiatry 2011, 20, 57-59. [PubMed]

18. Saito, H.; Shibuya, M.; Tuah, S.J.; Turjaman, M.; Takahashi, K.; Jamal, Y.; Segah, H.; Putir, P.E.; Limin, S.H. Initial screening of fast-growing tree species being tolerant of dry tropical peatlands in Central Kalimantan, Indonesia. Indones. J. For. Res. 2005, 5, 107-115. [CrossRef]

19. Mohibbe Azam, M.; Waris, A.; Nahar, N.M. Prospects and potential of fatty acid methyl esters of some non-traditional seed oils for use as biodiesel in India. Biomass Bioenergy 2005, 29, 293-302. [CrossRef]

20. Mekala, N.K.; Potumarthi, R.; Baadhe, R.R.; Gupta, V.K. Current Bioenergy Researches: Strengths and Future Challenges. In Bioenergy Research: Advances and Applications; Elsevier: Amsterdam, The Netherlands, 2014; pp. 1-21.

21. Edmeades, D.C.; Wheeler, D.M. Measurement of $\mathrm{pH}$ in New Zealand soils: An examination of the effect of electrolyte, electrolyte strength, and soil solution ratio. N. Z. J. Agric. Res. 1990, 33, 105-109. [CrossRef]

22. Gavriloaiei, T. The influence of electrolyte solutions on soil pH measurements. Rev. Chim. 2012, 63, 396-400.

23. Penman, J.; Gytarsky, M.; Hiraishi, T.; Krug, T.; Dina, K.; Pipatti, R.; Buendia, L.; Miwa, K.; Todd, N.; Tanabe, K. IPCC Good Practice Guidance for Land Use, Land-Use Change and Forestry; IPCC National Greenhouse Gas Inventories Programme Technical Support Unit: Kamiyamaguchi Hayama, Kanagawa, Japan, 2003. 
24. Meher, L.C.; Vidya Sagar, D.; Naik, S.N. Technical aspects of biodiesel production by transesterification-A review. Renew. Sustain. Energy Rev. 2006, 10, 248-268. [CrossRef]

25. Hofstrand, D. Liquid Fuel Measurements and Conversions; Lowa State University of Science and Techonology: Ames, IA, USA, 2008.

26. Demİrbas, A. Bioethanol from cellulosic materials: A renewable motor fuel from biomass. Energy Sources 2005, 27, 327-337. [CrossRef]

27. Crosson, P. The on-farm economic costs of soil erosion. In Advances in Soil Science: Methods for Assessment of Soil Degradation; Lal, R., Blum, W.H., Valentine, C., Stewart, B.A., Eds.; CRC Press: Boca Raton, FL, USA, 1997; pp. 495-511.

28. Borchard, N.; Artati, Y.; Lee, S.-M.; Baral, H. Sustainable forest management for land rehabilitation and provision of biomass-energy. CIFOR Br. 2017, 41, 4. [CrossRef]

29. Ramachandran Nair, P.K.; Mohan Kumar, B.; Nair, V.D. Agroforestry as a strategy for carbon sequestration. J. Plant Nutr. Soil Sci. 2009, 172, 10-23. [CrossRef]

30. Vieira, D.L.M.; Holl, K.D.; Peneireiro, F.M. Agro-Successional Restoration as a Strategy to Facilitate Tropical Forest Recovery. Restor. Ecol. 2009, 17, 451-459. [CrossRef]

31. Gruenewald, H.; Brandt, B.K.V.; Schneider, B.U.; Bens, O.; Kendzia, G.; Hüttl, R.F. Agroforestry systems for the production of woody biomass for energy transformation purposes. Ecol. Eng. 2007, 29, 319-328. [CrossRef]

32. Wichtmann, W.; Schröder, C.; Joosten, H. Paludiculture as an inclusive solution. In Paludiculture-Cultivation of Wet Peatlands: Climate Protection-Biodiversity-Regional Economic Benefits; Wichtmann, W., Schröder, C., Joosten, H., Eds.; Schweizerbart Science Publishers: Stuttgart, Germany, 2016; pp. 3-20.

33. Chazdon, R.L. Tropical forest recovery: Legacies of human impact and natural disturbances. Perspect. Plant Ecol. Evol. Syst. 2003, 6, 51-71. [CrossRef]

34. Popp, A.; Lotze-Campen, H.; Leimbach, M.; Knopf, B.; Beringer, T.; Bauer, N.; Bodirsky, B. On sustainability of bioenergy production: Integrating co-emissions from agricultural intensification. Biomass Bioenerg 2011, 35, 4770-4780. [CrossRef]

35. Chimera, C.; Buddenhagen, C.; Clifford, P.M. Biofuels: The risks and dangers of introducing invasive species. Biofuels 2010, 1, 785-796. [CrossRef]

36. Ziller, S.; Howard, G. Alien alert-biofuel plants may be invasive. Bioenergy Business 2008, 14-16.

37. Richardson, D.M.; Blanchard, R. Learning from our mistakes: Minimizing problems with invasive biofuel plants. Curr. Opin. Environ. Sustain. 2011, 3, 36-42. [CrossRef]

38. Wicke, B.; Sikkema, R.; Dornburg, V.; Junginger, M.; Faaij, A. Drivers of land use change and the role of palm oil production in Indonesia and Malaysia: Overview of past developments and future projections. Sci. Technol. Soc. 2008, 44, 53-60.

39. Wahid, M.B.; Abdullah, S.N.A.; Henson, I.E. Oil Palm-Achievements and Potential. Plant Prod. Sci. 2005, 8 , 288-297. [CrossRef]

40. Verheye, W. Growth and production of oil palm. In Land Use, Land Cover and Soil Sciences; Verheye, W., Ed.; UNESCO-EOLSS Publishers: Oxford, UK, 2010.

41. Tata, H.L.; van Noordwijk, M.; Jasnari; Widayati, A. Domestication of Dyera polyphylla (Miq.) Steenis in peatland agroforestry systems in Jambi, Indonesia. Agrofor. Syst. 2016, 90, 617-630. [CrossRef]

42. Manuri, S.; Brack, C.; Noor'an, F.; Rusolono, T.; Anggraini, S.M.; Dotzauer, H.; Kumara, I. Improved allometric equations for tree aboveground biomass estimation in tropical dipterocarp forests of Kalimantan, Indonesia. For. Ecosyst. 2016, 3, 28. [CrossRef]

43. Günther, B.; Gebauer, K.; Barkowski, R.; Rosenthal, M.; Bues, C.-T. Calorific value of selected wood species and wood products. Eur. J. Wood Wood Prod. 2012, 70, 755-757. [CrossRef]

44. Demirbaş, A. Calculation of higher heating values of biomass fuels. Fuel 1997, 76, 431-434. [CrossRef]

(C) 2018 by the authors. Licensee MDPI, Basel, Switzerland. This article is an open access article distributed under the terms and conditions of the Creative Commons Attribution (CC BY) license (http://creativecommons.org/licenses/by/4.0/). 